\title{
HANDBOOK OF \\ ELECTRICAL POWER \\ SYSTEM DYNAMICS
}


IEEE Press

445 Hoes Lane

Piscataway, NJ 08854

\section{IEEE Press Editorial Board 2013}

John Anderson, Editor in Chief

$\begin{array}{lll}\text { Linda Shafer } & \text { Saeid Nahavandi } & \text { George Zobrist } \\ \text { George W. Arnold } & \text { David Jacobson } & \text { Tariq Samad } \\ \text { Ekram Hossain } & \text { Mary Lanzerotti } & \text { Dmitry Goldgof }\end{array}$

Om P. Malik

Kenneth Moore, Director of IEEE Book and Information Services (BIS) 


\section{HANDBOOK OF \\ ELECTRICAL POWER SYSTEM DYNAMICS}

Modeling, Stability, and Control

Edited by

Mircea Eremia

Electrical Power Systems Department

University "Politehnica" of Bucharest

Mohammad Shahidehpour

Illinois Institute of Technology

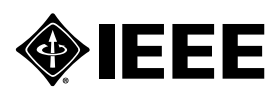

IEEE PRESS

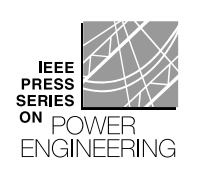

Mohamed E. El-Hawary, Series Editor

WILEY 
Copyright $(C) 2013$ by The Institute of Electrical and Electronics Engineers, Inc.

Published by John Wiley \& Sons, Inc., Hoboken, New Jersey. All rights reserved.

Published simultaneously in Canada.

No part of this publication may be reproduced, stored in a retrieval system, or transmitted in any form or by any means, electronic, mechanical, photocopying, recording, scanning, or otherwise, except as permitted under Section 107 or 108 of the 1976 United States Copyright Act, without either the prior written permission of the Publisher, or authorization through payment of the appropriate per-copy fee to the Copyright Clearance Center, Inc., 222 Rosewood Drive, Danvers, MA 01923, (978) 750-8400, fax (978) 750-4470, or on the web at www. copyright.com. Requests to the Publisher for permission should be addressed to the Permissions Department, John Wiley \& Sons, Inc., 111 River Street, Hoboken, NJ 07030, (201) 748-6011, fax (201) 748-6008, or online at http://www.wiley.com/go/permission.

Limit of Liability/Disclaimer of Warranty: While the publisher and author have used their best efforts in preparing this book, they make no representations or warranties with respect to the accuracy or completeness of the contents of this book and specifically disclaim any implied warranties of merchantability or fitness for a particular purpose. No warranty may be created or extended by sales representatives or written sales materials. The advice and strategies contained herein may not be suitable for your situation. You should consult with a professional where appropriate. Neither the publisher nor author shall be liable for any loss of profit or any other commercial damages, including but not limited to special, incidental, consequential, or other damages.

For general information on our other products and services or for technical support, please contact our Customer Care Department within the United States at (800) 762-2974, outside the United States at (317) 572-3993 or fax (317) 572-4002.

Wiley also publishes its books in a variety of electronic formats. Some content that appears in print may not be available in electronic formats. For more information about Wiley products, visit our web site at www.wiley.com.

\section{Library of Congress Cataloging-in-Publication Data:}

Handbook of electrical power system dynamics : modeling, stability, and control / edited by Mircea Eremia, Mohammad Shahidehpour.

$$
\text { pages } \mathrm{cm}
$$

Includes bibliographical references.

ISBN 978-1-118-49717-3 (cloth)

1. Electric power system stability-Mathematical models-Handbooks, manuals, etc. 2. Electric power systems-Control-Handbooks, manuals, etc. 3.

Electric machinery-Dynamics-Handbooks, manuals, etc. I. Eremia, Mircea.

II. Shahidehpour, M., 1955-

TK1001.H35 2012

$621.31-\mathrm{dc} 23$

Printed in the United States of America

10987765544321 
Acknowledgments $\quad$ xxv

$\begin{array}{ll}\text { Contributors } & \text { xxvii }\end{array}$

1. INTRODUCTION

Mircea Eremia and Mohammad Shahidehpour

PART I POWER SYSTEM MODELING AND CONTROL 7

2. SYNCHRONOUS GENERATOR AND INDUCTION MOTOR 9

Mircea Eremia and Constantin Bulac

2.1. Theory and Modeling of Synchronous Generator 9

2.1.1. Design and Operation Principles 9

2.1.2. Electromechanical Model of Synchronous Generator:
Swing Equation

2.1.3. Electromagnetic Model of Synchronous Generator 17

$\begin{array}{ll}\text { 2.1.3.1. Basic Equations } & 17\end{array}$

2.1.3.2. Park Transformation 24

2.1.3.3. Park Equations of Synchronous Generator 27

2.1.3.4. Representation of Synchronous Generator Equations
in Per Unit

2.1.3.5. Equivalent Circuits for the $d$ - and $q$-Axes $\quad 38$

2.1.3.6. Steady-State Operation of the Synchronous Generator 41

2.1.3.7. Synchronous Generator Behavior on Terminal Short Circuit 46

2.1.4. Synchronous Generator Parameters 55

2.1.4.1. Operational Parameters 55

2.1.4.2. Standard Parameters $\quad 59$

2.1.5. Magnetic Saturation 66

2.1.5.1. Open-Circuit and Short-Circuit Characteristics 67

2.1.5.2. Considering the Saturation in Stability Studies 69

2.1.6. Modeling in Dynamic State 73

2.1.6.1. Simplified Electromagnetic Models 73

2.1.6.2. Detailed Model in Dynamic State 82

2.1.7. Reactive Capability Limits 90 
2.1.7.1. Loading Capability Chart 90

2.1.7.2. The $V$ Curves $\quad 92$

2.1.8. Description and Modeling of the Excitation Systems 93

2.1.8.1. Components and Performances of Excitation Control System $\quad 93$

2.1.8.2. Types and Modeling of Excitation Systems 94

2.1.8.3. Control and Protective Functions 104

$\begin{array}{ll}\text { 2.1.8.4. Example } & 112\end{array}$

2.2. Theory and Modeling of the Induction Motor 114

2.2.1. Design and Operation Issues 114

2.2.2. General Equations of the Induction Motor 116

2.2.2.1. Electrical Circuit Equations 116

2.2.2.2. The $d-q$ Transformation $\quad 120$

2.2.2.3. Basic Equations in the $d-q$ Reference Frame 121

$\begin{array}{ll}\text { 2.2.2.4. Electric Power and Torque } & 123\end{array}$

2.2.3. Steady-State Operation of the Induction Motor 123

2.2.4. Electromechanical Model of Induction Motor 129

2.2.5. Electromagnetic Model of Induction Motor 131

References 134

\section{MODELING THE MAIN COMPONENTS OF THE CLASSICAL POWER PLANTS}

Mohammad Shahidehpour, Mircea Eremia, and Lucian Toma

3.1. Introduction

3.2. Types of Turbines 138

3.2.1. Steam Turbines 138

3.2.2. Gas Turbines 139

3.2.3. Hydraulic Turbines 140

$\begin{array}{ll}\text { 3.3. Thermal Power Plants } & 143\end{array}$

3.3.1. Generalities 143

3.3.2. Boiler and Steam Chest Models $\quad 145$

3.3.3. Steam System Configurations 148

3.3.4. General Steam System Model 151

3.3.5. Governing Systems for Steam Turbines 152

3.3.5.1. Mechanical Hydraulic Control (MHC) 153

3.3.5.2. Electrohydraulic Control (EHC) 155

3.3.5.3. Digital Electrohydraulic Control (DEHC) 157

3.3.5.4. General Model for Speed Governing Systems 157

3.4. Combined-Cycle Power Plants 158

3.4.1. Generalities 158

3.4.2. Configurations of Combined-Cycle Power Plants 159

3.4.3. Model Block Diagrams of Combined-Cycle Power Plant 160 
3.5. Nuclear Power Plants 167

3.6. Hydraulic Power Plants 169

3.6.1. Generalities 169

3.6.2. Modeling of Hydro Prime Mover Systems and Controls 171

3.6.2.1. General Block Diagram 171

3.6.2.2. Modeling of Turbine Conduit Dynamics 171

3.6.3. Hydro Turbine Governor Control Systems 174

3.6.3.1. Set Point Controller 174

3.6.3.2. The Actuator 176

$\begin{array}{ll}\text { References } & 177\end{array}$

$\begin{array}{ll}\text { 4. WIND POWER GENERATION } & 179\end{array}$

Mohammad Shahidehpour and Mircea Eremia

4.1. Introduction 179

4.2. Some Characteristics of Wind Power Generation 181

4.3. State of the Art Technologies 184

4.3.1. Overview of Generator Concepts 184

4.3.1.1. General Description $\quad 185$

4.3.1.2. Squirrel Cage Induction Generator $\quad 188$

4.3.1.3. Dynamic Slip-Controlled Wound Rotor
Induction Generator

4.3.1.4. Doubly Fed Induction Generator $\quad 190$

4.3.1.5. Wound Rotor Synchronous Generator $\quad 191$

4.3.1.6. Permanent Magnet Synchronous Generator 192

4.3.2. Overview of Wind Turbines Concepts 195

4.3.2.1. Fixed-Speed Wind Turbines 195

4.3.2.2. Variable-Speed Wind Turbines 195

4.3.3. Overview of Power Control Concepts 197

4.4. Modeling the Wind Turbine Generators 200

4.4.1. Model of a Constant-Speed Wind Turbine 200

4.4.2. Modeling the Doubly Fed Induction Generator Wind
Turbine System

4.4.2.1. DFIG Model 205

4.4.2.2. Drive Train of DFIG 207

4.4.2.3. Power Converter 209

4.4.2.4. Control Strategy for the DFIG 209

4.4.2.5. Aerodynamic Model and Pitch Angle Controller 215

$\begin{array}{ll}\text { 4.4.2.6. Operating Modes } & 217\end{array}$

4.4.3. Full-Scale Converter Wind Turbine $\quad 218$

4.4.3.1. General Model 218

4.4.3.2. Model of a Direct-Drive Wind Turbine with
Synchronous Generator

4.4.3.3. Control of Full-Scale Converter Wind Turbine 221 
4.5. Fault Ride-Through Capability

4.5.1. Generalities

4.5.2. Blade Pitch Angle Control for Fault Ride-Through

References

5. SHORT-CIRCUIT CURRENTS CALCULATION

Nouredine Hadjsaid, Ion Triştiu, and Lucian Toma

5.1. Introduction

229

5.1.1. The Main Types of Short Circuits

5.1.2. Consequences of Short Circuits

5.2. Characteristics of Short-Circuit Currents

5.3. Methods of Short-Circuit Currents Calculation

5.3.1. Basic Assumptions

5.3.2. Method of Equivalent Voltage Source

5.3.3. Method of Symmetrical Components

5.3.3.1. General Principles

5.3.3.2. The Symmetrical Components of Unsymmetrical Phasors

5.3.3.3. Sequence Impedance of Network Components

5.3.3.4. Unsymmetrical Fault Calculations

5.4. Calculation of Short-Circuit Current Components

5.4.1. Initial Symmetrical Short-Circuit Current $I_{\mathrm{k}}^{\prime \prime}$

5.4.1.1. Three-Phase Short Circuit

5.4.1.2. Phase-to-Phase Short Circuit

5.4.1.3. Phase-to-Phase Short Circuit with Earth Connection

5.4.1.4. Phase-to-Earth Short Circuit

5.4.2. Peak Short-Circuit Current $i_{\mathrm{p}}$

5.4.2.1. Three-Phase Short Circuit

5.4.2.2. Phase-to-Phase Short Circuit

5.4.2.3. Phase-to-Phase Short Circuit with Earth Connection

5.4.2.4. Phase-to-Earth Short Circuit

5.4.3. DC Component of the Short-Circuit Current

5.4.4. Symmetrical Short-Circuit Breaking Current $I_{\mathrm{b}}$

5.4.4.1. Far-from-Generator Short Circuit

5.4.4.2. Near-to-Generator Short Circuit

5.4.5. Steady-State Short-Circuit Current $I_{\mathrm{k}}$

5.4.5.1. Three-Phase Short Circuit of One Generator or One Power Station Unit

5.4.5.2. Three-Phase Short Circuit in Nonmeshed Networks

5.4.5.3. Three-Phase Short Circuit in Meshed Networks

5.4.5.4. Unbalanced Short Circuits 
Les Pereira

6.1. Introduction

6.2. Frequency Deviations in Practice 293

6.2.1. Small Disturbances and Deviations 293

6.2.2. Large Disturbances and Deviations 293

6.3. Typical Standards and Policies for "Active Power and Frequency

Control" or "Load Frequency Control" 294

6.3.1. UCTE Load Frequency Control 294

6.3.1.1. Primary Control is by Governors 295

6.3.1.2. Secondary Control by Automatic Generation
Controls (AGCs)

6.3.1.3. Tertiary Control 296

6.3.1.4. Self-Regulation of the Load 296

6.3.2. NERC (U.S.) Standards 296

6.3.3. Other Countries' Standards 297

6.4. System Modeling, Inertia, Droop, Regulation, and Dynamic
Frequency Response

6.4.1. Block Diagram of the System Dynamics and Load Damping 297

6.4.2. Effect of Governor Droop on Regulation 298

6.4.3. Increasing Load by Adjusting Prime Mover Power 298

6.4.4. Parallel Operation of Several Generators $\quad 298$

6.4.5. Isolated Area Modeling and Response $\quad 301$

6.5. Governor Modeling $\quad 302$

6.5.1. Response of a Simple Governor Model with Droop 303

6.5.2. Hydraulic Governor Modeling $\quad 304$

6.5.2.1. Hydraulic Turbines 304

6.5.2.2. Hydraulic Governors 305

6.5.2.3. Hydraulic Turbine Model 306

6.5.2.4. PID Governor 306

6.5.3. Performance of Hydrogovernors with Parameters Variation 307

6.5.3.1. Isolated System Governor Simulations 307

6.5.3.2. Interconnected System Governor Simulations 309

6.5.4. Thermal Governor Modeling 311

6.5.4.1. General Steam System Model 311

6.5.4.2. Gas Turbine Model 312

6.5.5. Development of a New Thermal Governor Model in the WECC 315

6.5.5.1. The New Thermal Governor Model 315

6.5.5.2. Analysis of Test Data: Thermal Versus Hydro Units 318

6.6. AGC Principles and Modeling 328

6.6.1. AGC in a Single-Area (Isolated) System 329

6.6.2. AGC in a Two-Area System, Tie-Line Control, Frequency Bias 329

6.6.3. AGC in Multiarea Systems 332 
6.7. Other Topics of Interest Related to Load Frequency Control 336

6.7.1. Spinning Reserves 336

6.7.2. Underfrequency Load Shedding and Operation in Islanding Conditions

References

\section{VOLTAGE AND REACTIVE POWER CONTROL}

\section{Sandro Corsi and Mircea Eremia}

7.1. Relationship Between Active and Reactive

Powers and Voltage

7.1.1. Short Lines

7.1.2. Taking into Account the Shunt Admittance 346

7.1.3. Sensitivity Coefficients 346

7.2. Equipments for Voltage and Reactive Power Control 347

7.2.1. Reactive Power Compensation Devices 347

7.2.1.1. Shunt Capacitors 347

7.2.1.2. Shunt Reactors 348

7.2.2. Voltage and Reactive Power Continuous Control Devices $\quad 349$

7.2.2.1. Synchronous Generators 349

7.2.2.2. Synchronous Compensators $\quad 350$

7.2.2.3. Static VAr Controllers and FACTS 351

7.2.3. On-Load Tap Changing Transformers 352

7.2.3.1. Generalities 352

7.2.3.2. Switching Technologies 355

7.2.3.3. Determination of the Current Operating Tap 362

7.2.3.4. Static Characteristic of the Transformer 363

7.2.3.5. Various Applications of the OLTC Transformers for Voltage and Reactive Power Control 366

$\begin{array}{ll}\text { 7.2.4. Regulating Transformers } & 371\end{array}$

7.2.4.1. In-Phase Regulating Transformer (IPRT) 371

7.2.4.2. Phase Shifting Transformers 372

7.3. Grid Voltage and Reactive Power Control Methods 374

$\begin{array}{ll}\text { 7.3.1. General Considerations } & 374\end{array}$

7.3.2. Voltage-Reactive Power Manual Control 377

7.3.2.1. Manual Voltage Control by Reactive Power Flow 378

7.3.2.2. Manual Voltage Control by Network Topology
Modification

7.3.3. Voltage-Reactive Power Automatic Control 378

7.3.3.1. Automatic Voltage Control of the Generator Stator Terminals 379

7.3.3.2. Automatic Voltage Control by Generator Line Drop Compensation 385

7.3.3.3. Automatic High-Side Voltage Control at a Power Plant 391 
7.4. Grid Hierarchical Voltage Regulation 399

7.4.1. Structure of the Hierarchy 399

7.4.1.1. Generalities 399

7.4.1.2. Basic SVR and TVR Concepts 401

7.4.1.3. Primary Voltage Regulation 402

7.4.1.4. Secondary Voltage Regulation: Architecture and Modeling 405

7.4.1.5. Tertiary Voltage Regulation 417

7.4.2. SVR Control Areas 418

7.4.2.1. Procedure to Select the Pilot Nodes and to Define the Control Areas 418

7.4.2.2. Procedure to Select the Control Generators 420

7.4.3. Power Flow Computation in the Presence of the Secondary

Voltage Regulation $\quad 422$

7.5. Implementation Study of the Secondary Voltage Regulation in Romania 423

7.5.1. Characteristics of the Study System 423

7.5.2. SVR Areas Selection 423

7.6. Examples of Hierarchical Voltage Control in the World 429

7.6.1. The French Power System Hierarchical Voltage Control 429

7.6.1.1. General Overview 429

7.6.1.2. Original Secondary Voltage Regulation 430

7.6.1.3. Coordinated Secondary Voltage Regulation 432

7.6.1.4. Performances and Results of Simulations 434

7.6.1.5. Conclusion on the French Hierarchical Voltage
Control System

7.6.2. The Italian Hierarchical Voltage Control System 435

7.6.2.1. General Overview 435

7.6.2.2. Improvements in the Power System Operation 438

7.6.2.3. Conclusions on the Italian Hierarchical Voltage
Control System

7.6.3. The Brazilian Hierarchical Voltage Control System 442

7.6.3.1. General Overview 442

7.6.3.2. Results of the Study Simulations 443

7.6.3.3. Conclusions on the Brazilian Voltage Control System 447

$\begin{array}{ll}\text { References } & 447\end{array}$

PART II POWER SYSTEM STABILITY AND PROTECTION

8. BACKGROUND OF POWER SYSTEM STABILITY 453

S.S. (Mani) Venkata, Mircea Eremia, and Lucian Toma

8.1. Introduction 453

8.2. Classification of Power Systems Stability 453

8.2.1. Rotor Angle Stability 454 
8.2.1.1. Small-Disturbance (or Small-Signal) Rotor Angle Stability 460

8.2.1.2. Large-Disturbance Rotor Angle Stability or Transient Stability

8.2.2. Voltage Stability

8.2.3. Frequency Stability

8.3. Parallelism Between Voltage Stability and Angular Stability 469

8.4. Importance of Security for Power System Stability 469

8.4.1. Power System States 470

8.4.2. Power Flow Security Limits 472

8.4.3. Services to Meet Power System Security Constraints 473

8.4.4. Dynamic Security Assessment 474

References

9. SMALL-DISTURBANCE ANGLE STABILITY AND ELECTROMECHANICAL OSCILLATION DAMPING

Roberto Marconato and Alberto Berizzi

9.1. Introduction 477

9.2. The Dynamic Matrix 478

9.2.1. Linearized Equations $\quad 478$

9.2.2. Building the Dynamic Matrix 481

9.3. A General Simplified Approach 482

9.3.1. Inertia and Synchronizing Power Coefficients 483

9.3.2. Electromechanical Oscillations 486

9.3.2.1. Oscillation Modes 486

9.3.2.2. Oscillation Amplitudes and Participation Factors 489

9.3.3. Numerical Examples 493

9.3.3.1. Application 1: Two-Area Test System 494

9.3.3.2. Application 2: Three-Area Test System 497

9.4. Major Factors Affecting the Damping of Electromechanical Oscillations 501

9.4.1. Introduction 501

9.4.2. Single Machine-Infinite Bus System: A Simplified Approach 503

9.4.3. Single Machine-Infinite Bus System: A More Accurate Approach 507

9.4.3.1. Introduction 507

9.4.3.2. Contribution to Damping Due to Generator Structure 512

9.4.3.3. Contribution of the Primary Voltage Control 514

9.4.3.4. Effect of Primary Frequency Control 537

9.4.3.5. Outline of Other Contributions 544

9.4.4. Summary of the Major Factors Affecting the Damping of

Electromechanical Oscillations $\quad 545$

9.5. Damping Improvement 546

9.5.1. Introduction $\quad 546$

9.5.2. Modal Synthesis Based on the Theory of Small Shift Poles $\quad 550$ 
9.5.3. PSSs on Excitation Control 553

9.5.3.1. Base Case and Theory 553

9.5.3.2. Synthesis of PSSs on Excitation Control: General Case 556

$\begin{array}{ll}\text { 9.5.4. Limitation on PSS Gains } & 561\end{array}$

9.6. Typical Cases of Interarea Or Low-Frequency

Electromechanical Oscillations $\quad 564$

$\begin{array}{ll}\text { References } & 568\end{array}$

\section{TRANSIENT STABILITY $\quad 570$}

Nikolai Voropai and Constantin Bulac

$\begin{array}{ll}\text { 10.1. General Aspects } & 570\end{array}$

10.2. Direct Methods for Transient Stability Assessment 572

10.2.1. Equal Area Criterion 572

10.2.1.1. Fundamentals of Equal Area Criterion 572

10.2.1.2. Calculation of the Fault Clearing Time 575

10.2.1.3. Two Finite Power Synchronous Generators 579

10.2.2. Extended Equal Area Criterion-EEAC 580

10.2.3. The SIME (SIngle - Machine Equivalent) Method 582

10.2.3.1. Method Formulation 583

10.2.3.2. Criteria and Degree of Instability 585

10.2.3.3. Criteria and Corresponding Stability Reserve 585

10.2.3.4. Identification of the OMIB Equivalent 586

10.2.4. Direct Methods Based on Lyapunov's Theory 587

10.2.4.1. Lyapunov's Method 587

10.2.4.2. Designing the Lyapunov Function $\quad 590$

10.2.4.3. Determination of Equilibrium 594

10.2.4.4. Extension of the Direct Lyapunov's Method 596

$\begin{array}{ll}\text { 10.2.4.5. New Approaches } & 601\end{array}$

10.3. Integration Methods for Transient Stability Assessment 603

10.3.1. General Considerations $\quad 603$

$\begin{array}{ll}\text { 10.3.2. Runge-Kutta Methods } & 608\end{array}$

10.3.3. Implicit Trapezoidal Rule $\quad 609$

10.3.4. Mixed Adams-BDF Method 611

$\begin{array}{ll}\text { 10.4. Dynamic Equivalents } & 614\end{array}$

$\begin{array}{ll}\text { 10.4.1. Generalities } & 614\end{array}$

10.4.2. Simplification of Mathematical Description of a System 617

10.4.2.1. The Disturbance Impact Index 617

10.4.2.2. The Study of the Disturbance Impact Index 617

10.4.3. Estimating the System Element Significance 621

10.4.3.1. Index of the System Structural Connectivity 621

10.4.3.2. Significance of a System Element 622 
10.4.4. Coherency Estimation

623

10.4.4.1. Equation of the Mutual Motion of a Pair of Machines

623

10.4.4.2. Coherency Indices

625

10.4.4.3. Clustering of Coherency Indices

628

10.4.5. Equivalencing Criteria

631

10.4.6. Center of Inertia. Parameters of the Equivalent

634

10.5. Transient Stability Assessment of Large Electric Power

Systems

638

10.5.1. Characteristics of Large Electric Power System

638

10.5.2. Initial Conditions

639

10.5.3. Standard Conditions for Transient Stability Studies

639

10.5.3.1. Studied Conditions and Disturbances

639

10.5.3.2. Stability Margins

641

10.5.3.3. System Stability Requirements

642

10.5.4. Reducing the Studied Conditions by Structural Analysis

643

10.5.5. Using the Simplified Models and Direct Methods

644

10.6. Application

645

References

651

\section{VOLTAGE STABILITY}

Mircea Eremia and Constantin Bulac

$\begin{array}{ll}\text { 11.1. Introduction } & 657\end{array}$

$\begin{array}{ll}\text { 11.2. System Characteristics and Load Modeling } & 658\end{array}$

$\begin{array}{ll}\text { 11.2.1. System Characteristics } & 658\end{array}$

11.2.2. Load Modeling $\quad 660$

11.2.2.1. Load Characteristics $\quad 660$

11.2.2.2. Static Models 662

11.2.2.3. Dynamic Models 664

$\begin{array}{ll}\text { 11.3. Static Aspects of Voltage Stability } & 667\end{array}$

11.3.1. Existence of Steady-State Solutions 667

11.3.2. Operating Points and Zones $\quad 670$

11.4. Voltage Instability Mechanisms: Interaction Between Electrical

Network, Loads, and Control Devices $\quad 674$

11.4.1. Interaction between Electrical Network and Load 674

11.4.2. Influence of the On-Load Tap Changer 676

11.4.2.1. Modeling the On-Load Tap Changing Dynamics 676

11.4.2.2. The Effect of Automatic Tap Changing on the Possible Operating Points 678

11.4.2.3. Influence of On-Load Tap Changing on the Voltage $\begin{array}{ll}\text { Stability } & 679\end{array}$

11.4.3. Effect of the Generated Reactive Power Limitation 683

11.4.4. The Minimum Voltage Criteria 686 
$\begin{array}{ll}\text { 11.5. Voltage Stability Assessment Methods } & 688\end{array}$

11.5.1. Overview of Voltage Collapse Criteria 688

11.5.2. Sensitivities Analysis Method: Local Indices 695

$\begin{array}{ll}\text { 11.5.3. Loading Margin as Global Index } & 698\end{array}$

11.5.4. Some Aspects of the Bifurcations Theory 702

$\begin{array}{ll}\text { 11.5.4.1. Generalities } & 702\end{array}$

11.5.4.2. Hopf Bifurcation 704

$\begin{array}{ll}\text { 11.5.4.3. Saddle-node Bifurcation } & 705\end{array}$

11.5.4.4. Singularity Induced Bifurcation 706

$\begin{array}{ll}\text { 11.5.4.5. Global Bifurcations } & 707\end{array}$

11.5.5. The Smallest Singular Value Technique. VSI Global
Index

11.5.6. Modal Analysis of the Reduced Jacobian Matrix 711

11.5.6.1. The $V$ - $Q$ Variation Modes of the Power System 712

11.5.6.2. Definition of Participation Factors in Voltage

Stability Analysis $\quad 714$

$\begin{array}{ll}\text { 11.6. Voltage Instability Countermeasures } & 716\end{array}$

$\begin{array}{ll}\text { 11.6.1. Some Confusions } & 716\end{array}$

11.6.2. Load Shedding: An Emergency Measure 717

$\begin{array}{ll}\text { 11.6.3. Shunt Capacitor Switching } & 719\end{array}$

11.6.4. Extending the Voltage Stability Limit by FACTS Devices 719

11.6.5. Countermeasures Against the Destabilizing Effect of the
Load Tap Changer

$\begin{array}{ll}\text { 11.7. Application } & 724\end{array}$

$\begin{array}{ll}\text { References } & 733\end{array}$

12. POWER SYSTEM PROTECTION

Klaus-Peter Brand and Ivan De Mesmaeker

$\begin{array}{ll}\text { 12.1. Introduction } & 737\end{array}$

$\begin{array}{ll}\text { 12.1.1. Motivation } & 737\end{array}$

$\begin{array}{ll}\text { 12.1.2. The Task of Protection } & 738\end{array}$

12.1.3. Basic Protection Properties and Resulting
Requirements

12.1.4. From System Supervision to Circuit Breaker Trip 739

12.1.5. Main Operative Requirements 740

$\begin{array}{ll}\text { 12.1.5.1. Selectivity } & 740\end{array}$

$\begin{array}{ll}\text { 12.1.5.2. Reliability } & 740\end{array}$

12.1.5.3. Speed and Performance 741

$\begin{array}{ll}\text { 12.1.5.4. Adaptation } & 741\end{array}$

12.1.5.5. Adaptive Protection 741

$\begin{array}{ll}\text { 12.1.5.6. Backup Protection } & 741\end{array}$ 
12.1.5.7. General Remarks About Features Like Performance, Reliability, and Availability

12.1.6. Advantages of State-of-the-Art Protection 742

12.2. Summary of IEC 61850

12.3. The Protection Chain in Details

12.3.1. Copper Wires vs. Serial Links

12.3.2. Supervision

12.3.3. Values Measured for Protection

12.3.3.1. Nonelectrical Values

12.3.3.2. Electrical Values

12.3.4. Data Acquisition from Sensors

12.3.4.1. Sensors

12.3.4.2. A/D Conversion and Merging Unit

12.3.4.3. Time Synchronization

12.3.5. Protection Data Processing

12.3.5.1. General

12.3.5.2. Trip Decision and Related Information

12.3.5.3. Other Data Handling Features

12.3.6. Data Sending to the Actuators

12.3.7. Process Interface

12.3.8. Circuit Breaker

12.3.9. Power Supply

12.4. Transmission and Distribution Power System Structures

12.5. Properties of the Three-Phase Systems Relevant for Protection

12.5.1. Symmetries

12.5.2. Unbalance

12.5.3. Symmetrical Components

12.6. Protection Functions Sorted According to the Objects Protected

12.6.1. Protection Based on Limits of Locally Measured Values

12.6.1.1. Overcurrent and Time Overcurrent Protection

12.6.1.2. Overload Protection

12.6.1.3. Frequency Protection

12.6.1.4. Voltage Protection

12.6.1.5. Limit Supervision and Protection

12.6.1.6. Protection with Improvement of Selection by Time Delays

12.6.1.7. Protection with Improvement of Selection by

Communication

12.6.2. Protection with Fault Direction Detection 
12.6.3. Impedance Protection 766

12.6.3.1. Distance Protection 766

12.6.3.2. Special Impedance-Based Functions 768

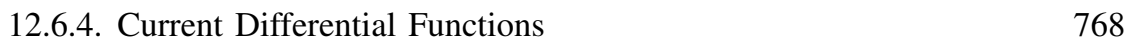

12.6.4.1. Differential Protection 768

12.6.4.2. Application Issues for Busbar Protection 770

12.6.4.3. Application Issues for Line Differential Protection 771

12.6.4.4. Comparative Protection as Simplified Differential Protection

12.6.5. Protection-Related Functions 772

12.6.5.1. Breaker Failure Protection 772

$\begin{array}{ll}\text { 12.6.5.2. Autoreclosing } & 772\end{array}$

12.6.5.3. Synchrocheck 773

12.7. From Single Protection Functions to System Protection 773

12.7.1. Single Function and Multifunctional Relays 773

12.7.2. Adaptive Protection 774

$\begin{array}{ll}\text { 12.7.3. Distributed Protection } & 774\end{array}$

12.7.3.1. Differential Object Protection Functions 774

12.7.3.2. Directional Object Protection Functions 775

$\begin{array}{ll}\text { 12.7.4. Wide Area Protection } & 775\end{array}$

12.7.5. General Guide 776

12.7.5.1. General Recommendations for Protection Application 776

$\begin{array}{ll}\text { 12.7.6. Security and Dependability } & 779\end{array}$

$\begin{array}{ll}\text { 12.7.7. Summary } & 780\end{array}$

$\begin{array}{ll}\text { 12.8. Conclusions } & 780\end{array}$

Annex 12.1. Identification of Protection Functions 780

$\begin{array}{ll}\text { A.12.1. General Remarks } & 780\end{array}$

A.12.1.1. IEEE Device Numbers $\quad 780$

$\begin{array}{ll}\text { A.12.1.2. IEC Designation } & 781\end{array}$

A.12.1.3. Logical Nodes Names $\quad 781$

$\begin{array}{ll}\text { A.12.2. Identification List } & 781\end{array}$

$\begin{array}{ll}\text { References } & 785\end{array}$

PART III GRID BLACKOUTS AND RESTORATION PROCESS 787

\section{MAJOR GRID BLACKOUTS: ANALYSIS, CLASSIFICATION, AND PREVENTION $\quad 789$}

Yvon Besanger, Mircea Eremia, and Nikolai Voropai

13.1. Introduction $\quad 789$

13.2. Description of Some Previous Blackouts 792

13.2.1. August 14, 2003 Northeast United States and Canada Blackout 793

$\begin{array}{ll}\text { 13.2.1.1. Precondition } & 793\end{array}$ 
13.2.1.2. Initiating Events

13.2.1.3. Cascading Events 795

13.2.1.4. Final State 801

13.2.1.5. What Stopped the Cascade Spreading? 801

13.2.1.6. Causes of Blackout 802

13.2.1.7. Recommendations to Prevent Blackouts 804

13.2.2. September 28, 2003 Italy Blackout 805

$\begin{array}{ll}\text { 13.2.2.1. Precondition } & 805\end{array}$

13.2.2.2. Initiating Events 806

13.2.2.3. Cascading Events $\quad 806$

13.2.2.4. Final State 810

13.2.2.5. Restoration $\quad 811$

13.2.2.6. Root Causes of the Blackout 811

13.2.2.7. Recommendations to Prevent Blackouts 811

13.2.3. September 23, 2003 Eastern Denmark and Southern

Sweden Blackout

812

13.2.3.1. Precondition $\quad 812$

13.2.3.2. Initiating Events $\quad 812$

$\begin{array}{ll}\text { 13.2.3.3. Cascading Events } & 812\end{array}$

13.2.3.4. Final State 812

13.2.4. January 12, 2003 Blackout in Croatia 812

$\begin{array}{ll}\text { 13.2.4.1. Precondition } & 812\end{array}$

13.2.4.2. Initiating Events $\quad 813$

13.2.4.3. Cascading Events 813

$\begin{array}{ll}\text { 13.2.4.4. Final State } & 813\end{array}$

13.2.5. May 25, 2005 Blackout in Moscow 814

$\begin{array}{ll}\text { 13.2.5.1. Precondition } & 814\end{array}$

$\begin{array}{ll}\text { 13.2.5.2. Initiating Events } & 814\end{array}$

13.2.5.3. Cascading Events $\quad 816$

$\begin{array}{ll}\text { 13.2.5.4. Final State } & 816\end{array}$

13.2.6. July 12, 2004 Greece Blackout $\quad 816$

$\begin{array}{ll}\text { 13.2.6.1. Precondition } & 816\end{array}$

13.2.6.2. Initiating Events $\quad 816$

$\begin{array}{ll}\text { 13.2.6.3. Cascading Events } & 817\end{array}$

$\begin{array}{ll}\text { 13.2.6.4. Final State } & 817\end{array}$

13.2.7. July 2, 1996 Northwest U.S. Blackout 817

$\begin{array}{ll}\text { 13.2.7.1. Precondition } & 817\end{array}$

$\begin{array}{ll}\text { 13.2.7.2. Initiating Events } & 817\end{array}$

$\begin{array}{ll}\text { 13.2.7.3. Cascading Events } & 817\end{array}$

$\begin{array}{ll}\text { 13.2.7.4. Final State } & 818\end{array}$

13.2.8. August 10, 1996 Northwest U.S. Blackout 818

13.2.8.1. Precondition 818 
13.2.8.2. Initiating Events

818

$\begin{array}{ll}\text { 13.2.8.3. Cascading Events } & 818\end{array}$

13.2.8.4. Final State $\quad 818$

13.2.9. December 19, 1978 National Blackout in France 819

$\begin{array}{ll}\text { 13.2.9.1. Precondition } & 819\end{array}$

$\begin{array}{ll}\text { 13.2.9.2. Initiating Events } & 819\end{array}$

$\begin{array}{ll}\text { 13.2.9.3. Cascading Events } & 819\end{array}$

$\begin{array}{ll}\text { 13.2.9.4. Final State } & 820\end{array}$

$\begin{array}{ll}\text { 13.2.9.5. Restoration } & 820\end{array}$

$\begin{array}{ll}\text { 13.2.9.6. Causes of Blackout } & 820\end{array}$

13.2.10. January 12, 1987 Western France Blackout 820

$\begin{array}{lr}\text { 13.2.10.1. Precondition } & 820\end{array}$

13.2.10.2. Initiating Events $\quad 820$

$\begin{array}{ll}\text { 13.2.10.3. Cascading Events } & 820\end{array}$

13.2.10.4. Emergency Actions $\quad 821$

$\begin{array}{ll}\text { 13.2.10.5. Causes of Blackout } & 821\end{array}$

13.2.11. March 13, 1989 Hydro-Quebec System Blackout Response to Geomagnetic Disturbance $\quad 822$

$\begin{array}{ll}\text { 13.2.11.1. Precondition } & 822\end{array}$

13.2.11.2. Initiating and Cascading Events $\quad 823$

13.2.11.3. Causes of the SVC Tripping 823

$\begin{array}{ll}\text { 13.2.11.4. Equipment Damage } & 825\end{array}$

13.2.11.5. Lessons Learned $\quad 825$

13.2.12. January 17, 1995 Japan Blackout After Hanshin Earthquake 826

$\begin{array}{ll}\text { 13.2.12.1. Precondition } & 826\end{array}$

13.2.12.2. Supply and Demand $\quad 826$

13.2.12.3. Damage to Electric Power Facilities $\quad 827$

13.2.12.4. Restoration of Electricity Supply 828

13.2.13. European Incident of November 4, $2006 \quad 830$

$\begin{array}{lr}\text { 13.2.13.1. Precondition } & 830\end{array}$

13.2.13.2. Initiating Events $\quad 830$

13.2.13.3. Cascading Events $\quad 832$

13.2.13.4. Final State 833

13.2.13.5. Resynchronization $\quad 835$

13.2.14. Some Lessons Learned 835

$\begin{array}{ll}\text { 13.3. Analysis of Blackouts } & 835\end{array}$

13.3.1. Classification of Blackouts $\quad 836$

13.3.1.1. Precondition $\quad 836$

13.3.1.2. Initiating Events $\quad 837$

$\begin{array}{ll}\text { 13.3.1.3. Cascading Events } & 837\end{array}$

13.3.2. Blackouts: Types of Incidents $\quad 840$

13.3.3. Mechanisms of Blackouts 841 
13.3.3.1. Voltage Collapse 842

13.3.3.2. Frequency Collapse

842

13.3.3.3. Cascading Overload

843

13.3.3.4. System Separation

13.3.3.5. Loss of Synchronism

13.3.3.6. Generalization

13.4. Economical and Social Effects

13.5. Recommendations for Preventing Blackouts $\quad 849$

13.6. On Some Defense and Restoration Actions $\quad 850$

13.6.1. Defense Actions $\quad 851$

13.6.2. Restoration Actions $\quad 854$

13.7. Survivability/vulnerability of Electric Power Systems 856

13.7.1. Introduction 856

13.7.2. Conception $\quad 857$

13.7.3. Technology of Study 858

13.7.4. Concluding Remarks $\quad 859$

$\begin{array}{lr}\text { 13.8. Conclusions } & 860\end{array}$

Acknowledgments $\quad 860$

$\begin{array}{ll}\text { References } & 860\end{array}$

\section{RESTORATION PROCESSES AFTER BLACKOUTS 864}

Alberto Borghetti, Carlo Alberto Nucci, and Mario Paolone

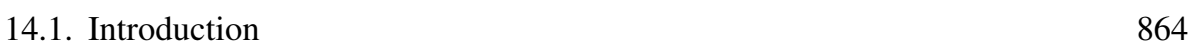

14.2. Overview of The Restoration Process 865

14.2.1. System Restoration Stages, Duration, Tasks, and Typical Problems 866

14.2.2. New Requirements 868

14.3. Black-Start-Up Capabilities of Thermal Power Plant: Modeling
and Computer Simulations

14.3.1. Black-Start-Up of a Steam Group Repowered by a Gas Turbine 869

14.3.1.1. Black-Start-up Capability of a Single Steam Group $\quad 870$

14.3.1.2. Black-Start-Up Capability of a Steam Group Repowered by a Gas Turbine

14.3.1.3. Control System Modifications to Improve Black-Start-Up Capabilities

14.3.2. Black-Start-Up of a Combined-Cycle Power Plant 877

14.3.2.1. Analysis of the Energization Maneuvers 878

$\begin{array}{ll}\text { 14.3.2.2. Analysis of the Islanding Maneuvers } & 879\end{array}$

14.3.2.3. Description of Some Islanding Tests and Obtained
Experimental Results

14.4. Description of Computer Simulators $\quad 888$ 
14.4.1. Simulator of a Steam Group Repowered with a Gas Turbine $\quad 888$

14.4.1.1. Gas Turbine Model and Its Validation $\quad 889$

14.4.1.2. Steam Section Modeling and Its Validation $\quad 889$

14.4.2. Simulator of a Combined-Cycle Power Plant 892

14.5. Concluding Remarks 896

References $\quad 896$

\section{COMPUTER SIMULATION OF SCALE-BRIDGING TRANSIENTS} IN POWER SYSTEMS

900

Kai Strunz and Feng Gao

15.1. Bridging of Instantaneous and Phasor Signals 901

$\begin{array}{ll}\text { 15.2. Network Modeling } & 903\end{array}$

15.2.1. Companion Model for Network Branches 903

15.2.2. Direct Construction of Nodal Admittance Matrix 906

$\begin{array}{ll}\text { 15.3. Modeling of Power System Components } & 909\end{array}$

15.3.1. Multiphase Lumped Elements 909

15.3.2. Transformer 911

15.3.3. Transmission Line $\quad 912$

$\begin{array}{ll}\text { 15.3.3.1. Single-Phase Line Model } & 912\end{array}$

$\begin{array}{ll}\text { 15.3.3.2. Multiphase Line Model } & 916\end{array}$

15.3.4. Synchronous Machine in $d q 0$ Domain 918

15.3.4.1. Electromagnetic and Mechanical Machine Equations 918

15.3.4.2. Calculation of Real Part of Stator Current 920

15.3.4.3. Calculation of Imaginary Part of Stator Current 920

15.3.4.4. Calculation of Rotor Speed and Angle 922

15.3.4.5. Integration with AC Network 922

15.3.4.6. Initialization 923

15.4. Application: Simulation of Blackout 923

References $\quad 926$

$\begin{array}{lr}\text { Index } & 929\end{array}$ 
Electricity is the driving factor of the modern world. Humanity is demanding more and more energy as the demand for better life quality, and industry development is increasing. The history of modern civilization begun more than one century ago when electricity generators and infrastructure for electricity transmission were invented. As the demand for electrical power has increased, the electrical power systems have been expanded over large distances and become more complex. There has been, thus, a continuous need for innovation to create more efficient and reliable components.

Recently, the electrical power systems have gone through a deregulation process, and electricity market has been created aiming to stimulate competition, achieve fair electrical energy price, encourage the investments for modernization and commissioning new power plants, etc. However, the immediate effects of the electricity market were additional problems in power system operation.

The limited conventional energy resources and the need for environment protection, on one hand, and the advantages of actual robust simulation hardware and software tools, on the other hand, encouraged the humanity to successfully exploit the Aeolian, solar, and other nonconventional resources. The share of electricity generation from renewable energy sources has significantly increased in the last years, and the targets are very ambitious for the future. Large wind farms are developed onshore and offshore, resulting in significant change in the generation pattern and thus changes in the power flow. Moreover, under the increasing share of generation from renewables, changes in power flows may sometimes occur quite often during one hour. This problem, in effect, requires strengthening the transmission grid.

The power system operators are, thus, facing bigger challenges than that in the past, such as limitations in scheduling and handling generation resources due to the electricity market, operation of the transmission networks close to their technical limits due to difficulties in constructing new transmission facilities, and generation uncertainties due to the intermittency and less inaccurate forecasts of the renewable energy sources, or even due to natural forces like earthquakes and storms.

The major grid blackouts experienced in the last years prove that investments and innovation are always required in the power system infrastructure, management, and education. The operational manual of the ENTSO-E network has been updated in order to prevent major incidents that occurred in the past due to permissive rules. In a strongly interconnected continental power system, as it is the ENTSO-E network, collaboration between power system operators based on clear rules is critical.

As a reaction to the technical issues of power systems, new concepts are under development. It is expected that the new ideas for more intelligent electrical networks (Smart Grids) and creation of continental supergrids may improve the power system security while satisfying the customers' needs as regards the quantity and quality. This may be seen as a new era of electricity. 
This book is a successful collection of theories and applications, from modeling for dynamic analysis, methods for stability assessment and control strategies that finally help the reader to understand the causes and effects of power system blackouts and, on one hand, to understand why some preventive actions are required in order to ensure appropriate security levels and avoid the blackouts. The authors of this book, both from academia and industry, are active specialists in CIGRE and IEEE-PES activities.

Education has been a critical ingredient for creating a sustainable electricity industry. Investment in education is the minimum condition to create professionals.

André Merlin President of CIGRE 


\section{ACKNOWLEDGMENTS}

The authors wish to take this opportunity to acknowledge all persons and institutions that contributed directly or indirectly in carrying out this book, either by technical or by editorial support.

Special acknowledgments are addressed to Prof. Prabha Kundur, president of Kundur Power System Solutions Inc., for his support and inspiring recommendations. His book on power system dynamics, a reference work in the field, has been also inspiring for several theories presented in this book.

For some chapters the authors benefited by the kindness of some institutions or companies, which permitted reprinting or adapting figures, equations, or excerpts. Special thanks are thus addressed to Institute of Electrical and Electronics Engineers (IEEE), International Electrotechnical Committee (IEC), Conseil International des Grands Réseaux Électriques-International Council on Large Electric Systems (CIGRE), as well as John Wiley \& Sons, Inc. for their reprinting permission and support. Acknowledgments are also addressed to Schneider Electric for the implicit permission to reprint some excerpts.

The authors express their gratitude to Prof. Ronald Harley (GeorgiaTech) for his permission to reprint some excerpts in Chapter 2. A stamp on the theory presented in Chapter 2 is also due to Prof. Eugeniu Potolea (University "Politehnica" of Bucharest) to whom the authors would like to address special thanks. Acknowledgments are extended to Prof. Mihaela Morega for recommendations at Chapter 2 and Prof. Florin Alexe for the recommendations at Chapter 3 (both are from University "Politehnica" of Bucharest).

Acknowledgments are addressed also to Prof. Daniel Roye and Prof. Seddik Bacha (INP Grenoble) for granting reprinting permission of some figures in Chapter 4 and for providing valuable recommendations.

In carrying out Chapter 5, Prof. Nicolae Golovanov (University "Politehnica" of Bucharest) has offered his expertise for which the authors would like to address thanks. Valuable ideas have been used in Chapter 5 following the collaboration with Dr. Jay C. Das, a consultant of AMEC Inc.

The authors would like to express their gratitude to Prof. Wilson Xu (University of Alberta) for granting the permission to reprint some excerpts in Chapter 11 . Acknowledgments are extended to Dr. Mrinal K. Pal (an independent consultant of MKPalConsulting) for granting the use of some ideas in Chapter 11. Some theories presented in Chapter 11 are the result also following the collaboration with Prof. Thierry Van Cutsem (Université de Liège) and emeritus professor Jacques Trecat (Faculté Polytechnique de Mons).

The authors of Chapter 13 would like to address thanks to Dmitry N. Efimov (Energy Systems Institute of the Russian Academy of Science, Irkutsk) and Dr. Lu Wei, a PhD of INP Grenoble, for their valuable contribution.

Writing a book is a complex work. The authors would like to extend their gratitude to Dr. Mircea Scutariu (Mott McDonald, Glasgow), Dr. Constantin Surdu (EdF France), 
Dr. Valentin Ilea, Dr. Ioana Pisicǎ, Dr. Petre Rǎzuşi, Dr. Florin Cǎtǎlin Ionescu and PhD students Cristian Virgil Cristea, Alexandru Mandiş, and Valeriu Iulian Presadǎ (University "Politehnica" of Bucharest) for their help in drawing figures and editing text and equations.

The authors gratefully acknowledge the excellent collaboration with the IEEE Press and John Wiley \& Sons, and address many thanks to Taisuke Soda, Mary Hatcher, Sanchari Sil, and Danielle LaCourciere for their patience and professionalism in carrying out the printed book.

Mircea Eremia Mohammad Shahidehpour 


\section{CONTRIBUTORS}

Alberto Berizzi, Dipartimento di Elettrotecnica, Politecnico di Milano, Piazza Leonardo da Vinci, 32, 20133 Milano, Italy

Yvon Besanger, INP Grenoble, LEG, 961 rue de la Houille Blanche, 38402 Saint Martin d'Heres, Cedex, France

Alberto Borghetti, Department of Electrical Engineering, University of Bologna, Viale Risorgimento 2, 40136 Bologna, Italy

Klaus-Peter Brand, Power Systems, ABB Switzerland Ltd., 72 Bruggerstrasse, CH-5400 Baden, Switzerland

Constantin Bulac, Department of Electrical Power Systems, University "Politehnica" of Bucharest, 313, Spl. Independenţei, 060042 Bucharest, Romania

Sandro Corsi, CESI, Via Rubattino 54, 20134 Milano, Italy

Mircea Eremia, Department of Electrical Power Systems, University "Politehnica" of Bucharest, 313, Spl. Independenţei, 060042 Bucharest, Romania

Feng Gao, Technische Universität Berlin, Einsteinnufer 11 (EMH-1), D-10587 Berlin, Germany

Nouredine Hadjsaid, INP Grenoble, LEG, 961 rue de la Houille Blanche, 38402 Saint Martin d'Heres, Cedex, France

Roberto Marconato, Dipartimento di Elettrotecnica, Politecnico di Milano, Piazza Leonardo da Vinci, 32, 20133 Milano, Italy

Ivan De Mesmaeker, Power Systems, ABB Switzerland Ltd., 72 Bruggerstrasse, CH-5400 Baden, Switzerland

Carlo Alberto Nucci, Department of Electrical Engineering, University of Bologna, Viale Risorgimento 2, 40136 Bologna, Italy

Mario Paolone, Department of Electrical Engineering, University of Bologna, Viale Risorgimento 2, 40136 Bologna, Italy

Les Pereira, Northern California Power Agency, 180 Cirby Way, Roseville, CA 95678, USA

Mohammad Shahidehpour, Electrical and Computer Engineering Department, Illinois Institute of Technology, 3301 South Dearborn Street, Chicago, IL 60616-3793, USA

Kai Strunz, Technische Universität Berlin, Einsteinnufer 11 (EMH-1), D-10587 Berlin, Germany

Lucian Toma, Department of Electrical Power Systems, University "Politehnica" of Bucharest, 313, Spl. Independenţei, 060042 Bucharest, Romania

Ion Triştiu, Department of Electrical Power Systems, University "Politehnica" of Bucharest, 313, Spl. Independenţei, 060042 Bucharest, Romania

S.S. (Mani) Venkata, Alstom Grid, 10865 Willows Road, NE, Redmond, WA 98052-2502, USA

Nikolai Voropai, Siberian Branch of the Russian Academy of Sciences, Energy Systems Institute, 130 Lermontov Street, Irkutsk 664033, Russia 